\title{
ZAGLADA FILOZOFÓW HELLEŃSKICH W IMPERIUM ROMANUM - OBRAZ MĘDRCÓW W RELACJI SOKRATESA Z KONSTANTYNOPOLA I HERMIASZA SOZOMENA
}

Hermiasz Sozomen pisał w swej Historii kościelnej o wyginięciu niemal doszczętnym najznakomitszych filozofów helleńskich. Wskazywał jednocześnie na pojawienie się nowej filozofii, uprawianej przez chrześcijańskich ascetów. Sozomen, tworząc swoją Historię kościelna, opierał się w dużym stopniu na dziele Sokratesa ${ }^{1}$. Mógł zatem ustosunkować się do poglądów głoszonych przez swego poprzednika. Obydwaj historycy w swych dziełach przykładali dużą wagę do filozofii, widząc w niej najwyższy stopień helleńskiego wykształcenia. W jaki sposób postrzegali zatem filozofię i filozofów? Czy ich spostrzeżenia były zbieżne, czy też różnili się w tej materii? Dlaczego Sozomen pisał o wyginięciu filozofów helleńskich, a Sokrates tego faktu nie dostrzegł? Na te pytania postaram się odpowiedzieć w niniejszym artykule.

Dekret cesarza Juliana Apostaty zabraniający chrześcijanom dostępu do wykształcenia helleńskiego stał się dla Sokratesa pretekstem, aby wyrazić opinię na temat helleńskiej filozofii. W przekonaniu Sokratesa pozwalała ona odkrywać Boga. Zdaniem tego historyka wielu spośród mędrców pogańskich było bliskich Jego poznania ${ }^{2}$. Wszak dlatego też Sokrates dowodził, że Chry-

${ }^{1}$ Zwracano na to uwage wielokrotnie, por. G.F. Chesnut, The first Christian Histories. Eusebius, Socrates, Sozomen, Theodoret and Evagrius, ThH 46, Paris 1977, 205; G. Sabbah, Introduction, w: Sozomène, Histoire Ecclésiastique, éd. J. Bidez - G.C. Hansen, SCh 306, Paris 1983, 59; F. Young, From Nicaea to Chalcedon, London 1983, 32; T.D. Barnes, Athanasius and Constantius, Cambridge 1993, 206; T. Urbainczyk, Observations on the differences between the Church Histories of Socrates and Sozomen, „Historia” 46 (1997) 355-356. W przekonaniu P. Janiszewskiego (Żywioty w stużbie propagandy, czyli po czyjej stronie stoi Bóg. Studium klęsk i rzadkich fenomenów przyrodniczych u historyków Kościoła w IV i V wieku, w: Chrześcijaństwo u schyłku starożytności. Studia źródtoznawcze, red. T. Derda - E. Wipszycka, t. 3, Kraków 2000, 153) Sozomen „chciał stworzyć konkurencyjne dla Sokratesa dzieło, bliższe kanonom klasycznej literatury i gustom klasycyzujących środowisk intelektualnych Konstantynopola".

${ }^{2}$ Por. Socrates, HE III 16, 10, hrsg. G.Ch. Hansen, GCS NF 1, Berlin 1995 (tłumaczenie polskie

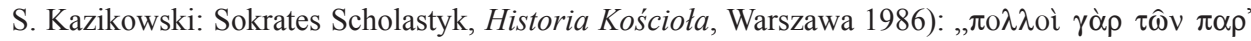

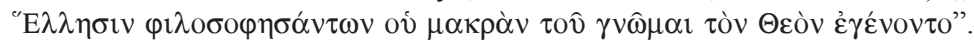


stus i jego uczniowie, co prawda „nie przyjęli pogańskiej nauki, ale też nie odrzucili jej precz, jakby to była nauka zgubna i szkodliwa"s. [...] decyzję w tej sprawie pozostawili rozeznaniu zainteresowanych"4. Historyk polemizował z poglądem, że wykształcenie pogańskie prowadzi do wielobóstwa. Edukację tę uważał za niezwykle użyteczna, gdyż uczyła zasad dialektyki, niezbędnych przy prowadzeniu wszelkich dyskusji, a szczególnie z poganami w materii religijnej ${ }^{5}$. Pamiętać trzeba, że uwielbiany przez Sokratesa Orygenes dowodził zgodności Objawienia z filozofią grecką, a zwłaszcza z platonizmem. W jego szkole zaś wykładano nie tylko teologię, ale też retorykę i filozofię ${ }^{6}$. Historyk ten wspomniał też, że Sokrates z Aten, uważany przezeń za największego filozofa helleńskiego, został „,skazany na śmierć jako ten, który podkopuje wiarę w uznane bóstwa"', a zatem widział w nim filozofa podważającego istniejący wówczas porządek religijny. Sozomen natomiast, wspominając śmierć Sokratesa, zauważył, że ten nie skorzystał z możliwości ucieczki, ale podporządkował się wydanemu nań niesprawiedliwemu wyrokowi z szacunku dla praw obowiązujących w Rzymie ${ }^{8}$. Zajmując się zaś kwestią polityki Juliana Apostaty wobec chrześcijan w analogicznym fragmencie do Historii kościelnej Sokratesa, Sozomen nie podjął wywodu poprzednika na temat zalet pogańskiej filozofii, czy w ogóle helleńskiego wykształcenia ${ }^{9}$. Pominął też milczeniem stwierdzenie Sokratesa, w którym ten podkreślał, że nauczyciele Kościoła „aż do swej starości [...] ćwiczyli się w naukach Hellenów"10. Czynili tak po to, zdaniem historyka, by doskonalić wymowę, rozwijać umiejętność logicznego myślenia i skutecznie zwalczać błędne poglądy pogan ${ }^{11}$. Sokrates podkreślał,

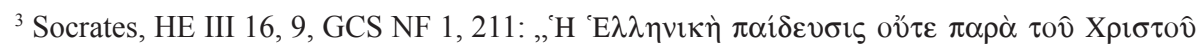

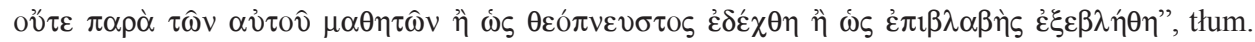
Kazikowski, s. 302.

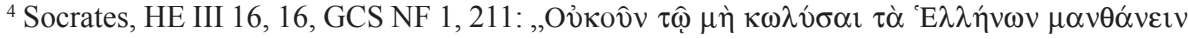

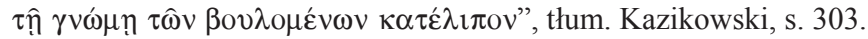

${ }^{5}$ Por. Socrates, HE III 16, 17. Podobnie na ten temat myślał m. in. Klemens Aleksandryjski (Stromata I 2, ed. C. Mondésert-M. Caster-P.Th. Camelot, SCh 30, Lyon 1951; zob. też H. Pietras, Poczatki teologii Kościoła, Kraków 2000, 123) dwukrotnie wzmiankowany przez Sokratesa w Historii kościelnej (II 35 i III 7).

${ }^{6}$ Por. C.P. Nautin, Origène. Sa vie et son oeuvre, Paris 1977, passim; H. Crouzel, Orygenes, tłum. J. Margański, Bydgoszcz 1996, passim.

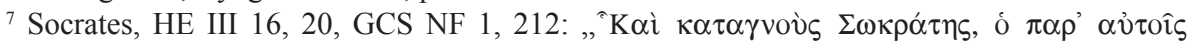

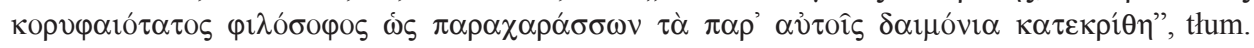
Kazikowski, s. 303.

${ }^{8}$ Por. Sozomenus, HE VI 35, 11, hrsg. J. Bidez - G.Ch. Hansen, GCS 50, Berlin 1960, 293, thum. S. Kazikowski: Hermiasz Sozomen, Historia Kościoła, Warszawa 1989.

${ }^{9}$ Por. Sozomenus, HE V 18.

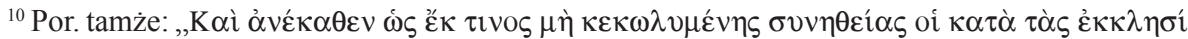

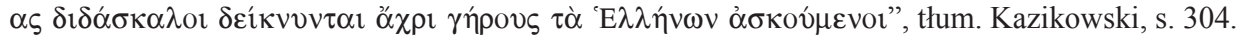

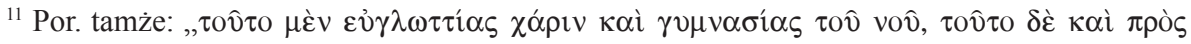

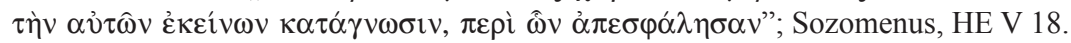


że filozofowie helleńscy nie osiagnęli tego, co w nauce najważniejsze ( $\tau \hat{\eta} \varsigma$

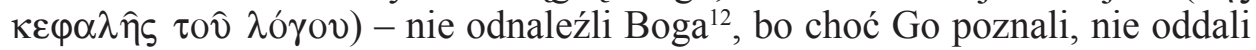
Mu czci jako Bogu' ${ }^{13}$.

W każdym razie w swoich Historiach kościelnych zarówno Sokrates, jak i Sozomen, wskazują na gruntowne wykształcenie helleńskie wielu postaci ówczesnego świata chrześcijańskiego. Wśród nich obydwaj historycy wymieniali Euzebiusza z Emezy. Wspomniany duchowny staranne wykształcenie otrzymać miał jeszcze w rodzinnym mieście, po czym studiował filozofię w Aleksandrii ${ }^{14}$. W relacji zarówno Sokratesa, jak i Sozomena, wszechstronnym wykształceniem wyróżniał się też Dydym Ślepy. Opanowawszy zasady filologii i retoryki, zajął się dziedziną filozofii, zaznajamiając się z arytmetyką muzyką i innymi naukami filozoficznymi, wykazując też biegłość w dialektyce. Odznaczał się także doskonałą znajomością Pisma Świętego ${ }^{15}$. W przekonaniu Sozomena:

„W sercu tego człowieka obrała sobie siedlisko mądrość wszechstronna, na którą złożyła się poezja i wymowa, astronomia i geometria wraz z arytmetyką, a wreszcie cała myśl filozoficzna"16.

Sokrates pełen zachwytu był dla życia, obyczajów, cnót, prawości i wykształcenia Bazylego z Cezarei i Grzegorza z Nazjanzu. Podkreślał, że obydwaj byli doskonale obeznani nie tylko z Pismem Świętym, ale też z nauką helleńską:

„Uznani za przygotowanych do wykładania retoryki, z wielu ust słyszeli zachętę, by się zechcieli poświęcić całkowicie nauczaniu. A gdy inni namawiali ich do zawodowego uprawiania wymowy sądowej, wzgardzili radami tak jednych, jak i drugich"17.

\footnotetext{
${ }^{12}$ Por. Socrates, HE III 16, 12, GCS NF 1, 211, thum. Kazikowski, s. 302.

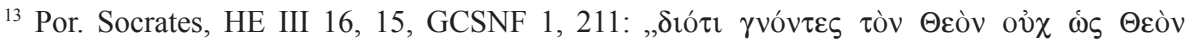

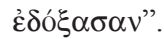

${ }^{14}$ Por. Socrates, HE II 9; Sozomenus, HE III 6.

${ }^{15}$ Por. Socrates, HE IV, 25; zob. R.A. Layton, Didymus the Blind and his circle in Late-Antique Alexandria, Urbana - Chicago 2004.

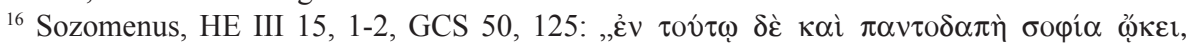

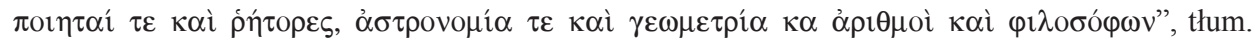
Kazikowski, s. 186.

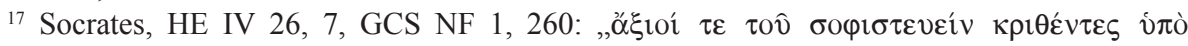

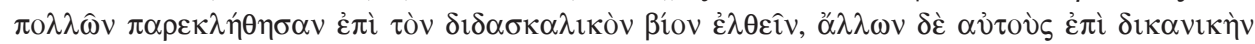

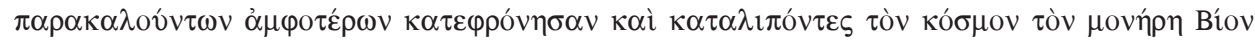

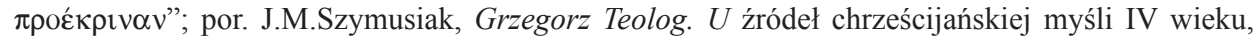
Poznań 1965, 41-75; P. Gruszka, Grzegorz z Nazjanzos wobec palacych problemów swojej epoki, „Acta Universitatis Wratislaviensis. Antiquitas” 8 (1979) nr 449, 275-297; B.E. Daley, Greogory of Nazianzus, New York 2006, 34-50; Ph. Rousseau, Basil of Caesarea, Berkeley 1994, passim; J. Naumowicz, Wstep, w: Św. Bazyli Wielki, Pisma ascetyczne, t. 1, ŹM 5, Kraków 1994, 9-55.
} 
Sozomen za Sokratesem również informował, że Bazyli z Grzegorzem zgłębiali przez jakiś czas nauki filozofów pogańskich. Mocno jednak podkreślał, iż obydwaj ,wzgardziwszy uprawianiem sofistyki i zawodem obrońcy sądowego postanowili prowadzić życie mędrców, kierujących się zasadami Kościoła"18. Gruntownie wykształcony był słynący z wymowy i ceniony przez Sokratesa nowacjański prezbiter Sisinnios. Biegły w naukach filozoficznych i w dialektyce, miał doskonale objaśniać Pismo Swięte ${ }^{19}$. Według Sozomena „oczytany w bogatej literaturze filozoficznej, tak pogańskiej, jak i kościelnej” był świetnym znawcą teorii filozoficznych oraz Pisma Świętego ${ }^{20}$. Obydwaj historycy wskazywali także, że Jan Chryzostom pobierał nauki u retora Libaniusza i filozofa Andragatiosa, nim skoncentrował się na lekturze Pisma Świę-

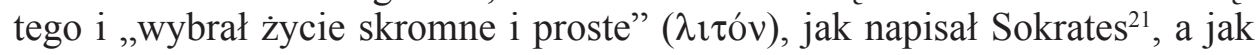
to ujął Sozomen, zajął się uprawianiem filozofii ,zgodnie z uświęconym prawem Kościoła"22. Podziwiany przez Sokratesa Attyk, jeden z następców Jana Chryzostoma na biskupim tronie Konstantynopola, łączyć miał „nieprzeciętne wykształcenie z pobożnością i bystrością umysłu”. W dodatku całe noce badał dzieła dawniejszych pisarzy, dzięki czemu nie mogli go wprawić w zakłopotanie ani filozofowie, ani retorzy ${ }^{23}$. W przeciwieństwie do Sokratesa Sozomen oceniał Attyka krytycznie. Pisał co prawda, że ten ,ilekroć pozwalały na to okoliczności zapoznawał się z dziełami najwybitniejszych autorów pogańskich”, mimo to jego zdaniem ,sprawiał wrażenie człowieka nie posiadającego gruntownej wiedzy"24. Sozomen wskazywał także, że wyświęcony potajemnie na biskupa Konstantynopola przez biskupów egipskich Maksym Cynik

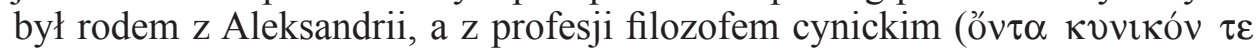

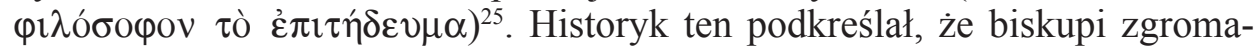
dzeni na soborze w Konstantynopolu unieważnili jego wyniesienie i wszelkie decyzje, które on jako biskup podjął. Zwraca uwagę brak krytycznej postawy

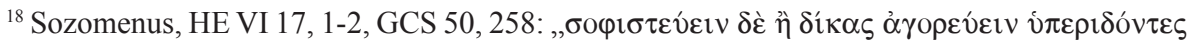


${ }_{19}$ Por. Socrates, HE V 10; V 21; VI 22. Na temat związków Sokratesa z nowacjanami zob. M. Wallraff, Socrates Scholasticus on the history of Novatianism, StPatr 29 (1997) 170-177; M. Stachura, Heretycy, schizmatycy i manichejczycy wobec Cesarstwa Rzymskiego (lata 324-428, wschodnia część Imperium), Kraków 2000, 174-193.

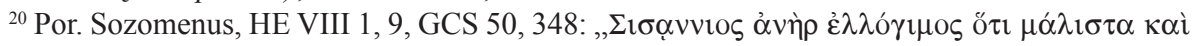

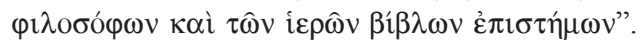

${ }^{21}$ Socrates, HE VI 3, 4, GCS NF 1, 314, thum. Kazikowski, s. 450.

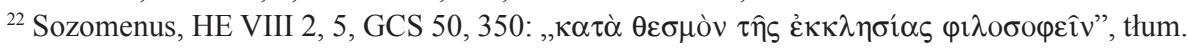
S. Kazikowski, s. 522. Nauczycielami Jana byli mnisi, kierujący tamtejszymi klasztorami Karterios i Diodor.

${ }^{23}$ Por. Socrates, HE VII 2. Michał Stachura (Heretycy, s. 109) podkreślał, że według Sokratesa Attyk potrafił być srogi, jak i łagodny dla heretyków.

${ }^{24}$ Sozomenus, HE VIII 27, 6, GCS 50, 388, thum. Kazikowski, s. 579.

${ }^{25}$ Por. Sozomenus, HE VII 29, 4, GCS 50, 346, tłum. Kazikowski, s. 517. 
historyka wobec Maksyma, która wynikała być może z faktu, że jak to zauważył Sozomen, był on gorliwym obrońcą nauki Soboru Nicejskiego.

W dziele Sokratesa z Konstantynopola uchwytny jest szacunek, z jakim odnoszono się do filozofów i ich ważna rola w życiu społecznym. Historyk ten wskazywał, że filozofa Sokratesa uważano za największego filozofa helleńskiego ${ }^{26}$ i najwybitniejszego spośród wszystkich filozofów ${ }^{27}$, Grecy podziwiali go „za jego roztropność, jak i sprawiedliwość oraz inne cnoty”28. Widziano w nim, wedle historyka, myśliciela wyrastającego ponad ludzki poziom i czczono jako ulubieńca bogów ${ }^{29}$. Podobnie też uwielbiany był Platon ${ }^{30}$. Wielką estymą obdarzano także Arystotelesa ${ }^{31}$. Sokrates z Konstantynopola wskazywał też na prestiż, jakim cieszyli się filozofowie w czasach mu współczesnych. Opisał np., jak to filozof Temistiusz z reprezentacją senatorów wyszedł naprzeciw cesarzowi Jowianowi, zanim ten wjechał do Konstantynopola i „wygłosił w jego obecności mowę z okazji objęcia konsulatu, którą powtórzył później także wobec tłumnie zebranej ludności w Konstantynopolu"32. W późniejszym czasie tenże Temistiusz wygłoszoną przez siebie mową ${ }^{33}$ miał wpłynać na cesarza Walensa, by ten złagodził swoją politykę wobec chrześcijan uznawanych przezeń za nieprawowiernych. Władca przekonany argumentacją filozofa miał ograniczyć liczbę wydawanych na nich wyroków śmierci ${ }^{34}$. Wielką estyma, wedle Sokratesa, cieszyła się też w Aleksandrii mistrzyni filozofii, Hypatia, córka filozofa Teona ${ }^{35}$ : swoim gruntownym wykształceniem przewyższyć miała współczesnych sobie filozofów. Posiadała znakomite rozeznanie we wszelkich doktrynach filozoficznych i była oblegana przez uczniów. Swą mądrością wymuszała dla siebie szacunek. Jak ujął to Sokrates:

„wszyscy nie tylko szanowali ją dla nieprzeciętnej roztropności, ale nawet czuli się [wobec niej] onieśmieleni”"36.

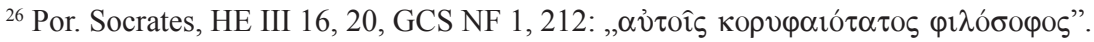

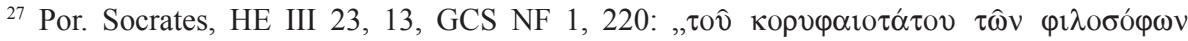
$\Sigma \omega \kappa \rho \alpha ́$ đovৎ".

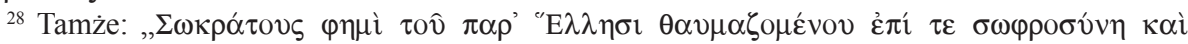
$\delta ı \kappa \alpha$

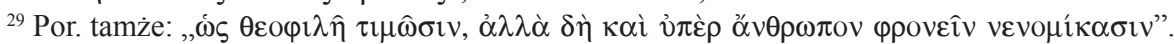

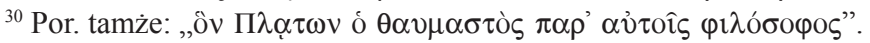

${ }^{31}$ Por. Socrates, HE II 35, 6-8.

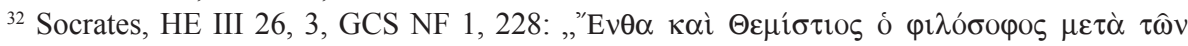

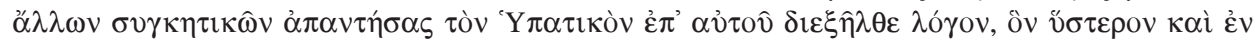

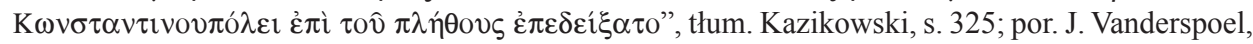
Themistius and the Imperial Court: oratory, civic duty and paideia from Constantius to Theodosius, Ann Arbor 1995, 135-154.

${ }^{33}$ Chodziło o tak zwaną Mowę dedykacyjną ( $\left.\pi \rho \circ \sigma \varphi \circ v \eta \tau \iota \kappa \hat{\omega}\right)$, por. Socrates, HE IV 32, 2.

${ }^{34}$ Por. Socrates, HE IV 32; zob. Vanderspoel, Themistius, s.155-186.

${ }^{35}$ Por. M. Dzielska, Hypatia z Aleksandrii, Kraków 2010, passim.

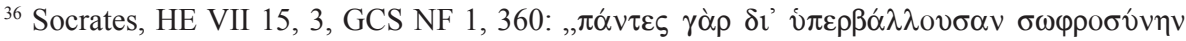

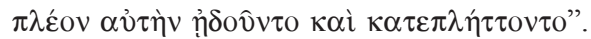


Wydaje się, że Sozomen chciał zaznaczyć swój odmienny w stosunku do Sokratesa pogląd na temat filozofii helleńskiej i uprawiających ją filozofów. Wyeliminował wszak ze swojej Historii kościelnej wszelkiego rodzaju stwierdzenia wyrażające podziw dla wielkich filozofów Sokratesa ${ }^{37}$, Platona $^{38}$ czy Arystotelesa ${ }^{39}$. Sozomen zrezygnował też z opisania przypadku Hypatii, nie czyniąc na jej temat choćby najmniejszej wzmianki. O Temistiuszu wspomniał co prawda, ale tylko o jego mowie wygłoszonej w obecności cesarza Walensa, po której władca ów miał złagodzić swoją politykę wobec ortodoksów ${ }^{40}$. Wzmiankując zaś na temat Sopatra, stojącego w czasach cesarza Konstantyna I na czele szkoły Plotyna, historyk ten zauważył, że ów z racji swego wykształcenia osiągnął wśród pogan najwyższe uznanie ${ }^{41}$. Zwrócił też uwagę na związek z pogaństwem niejakiego Olimpiosa, który miał upodabniać się

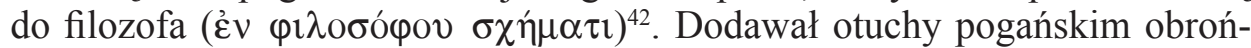
com Serapejonu, ale w konfrontacji z nadprzyrodzonym zjawiskiem, jakiego miał wówczas doświadczyć, opuścił ich w tajemnicy ${ }^{43}$. Sozomen zatem wiązał filozofów helleńskich z pogaństwem i wskazywał na ich wysoki prestiż, jakim cieszyli się wśród pogan. Jednocześnie eksponował ich lekkomyślność $(\pi \rho \circ \varepsilon \dot{\tau} \tau \varepsilon 1 \alpha)^{44}$, która doprowadziła ich do niemal doszczętnego wyginięcia ${ }^{45}$. Nieszczęście to sprowadziła na nich ówczesna elita filozofów, określana przez Sozomena jako ci, którzy wyróżniali się spośród ich ogółu. Owa grupa, nie mogąc pogodzić się z rozwojem chrześcijaństwa, usiłowała m.in. za pomoca różnorakich wróżb poznać osobę następcy panującego cesarza Walensa ${ }^{46}$. Ten jednak uznał ich działanie za zamach na swoje życie i zarządził represje. W ten sposób zginęli na stosie lub od miecza nie tylko niedoszli zamachowcy, ale też „najznakomitsi filozofowie na obszarze całego imperium”" ${ }^{47}$. Krwawa rzeź objęła także tych, którzy nosili strój filozofów. Ludzie innych profesji, aby

${ }^{37}$ Por. Sozomenus, HE Prologus; II 24; VI 35.

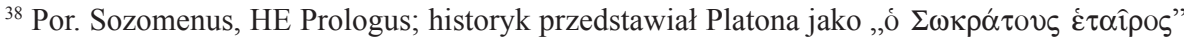
(II 24, 2)

${ }^{39}$ Por. Sozomenus, HE III 15; VII 17.

${ }^{40}$ Por. Sozomenus, HE VI 36-37.

${ }^{41}$ Por. Sozomenus, HE I 6.

${ }^{42}$ Por. Sozomemus, HE VII 15, 6, GCS 50, 320.

${ }^{43}$ Por. Sozomenus, HE VII 15.

${ }^{44}$ Por. Sozomenus, HE VI 35, 8.

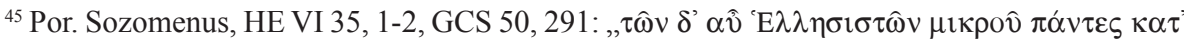

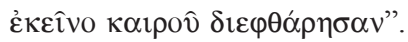

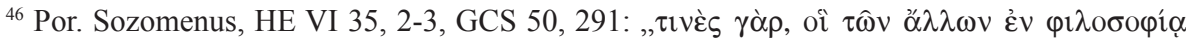

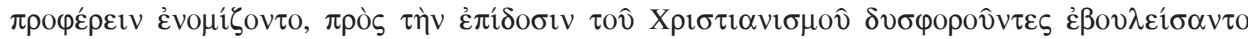

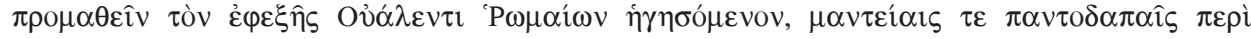

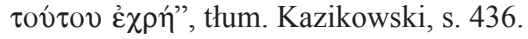

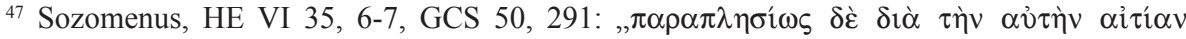

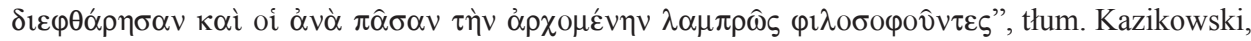
s. 437. 
uniknąc zagłady, przestali więc ubierać się w płaszcze typowe dla mędrców ${ }^{48}$, by nie ściągać na siebie podejrzenia, iż „oddawali się wróżbom i uczestniczyli w obrzędach pogańskich" ${ }^{49}$. W analogicznym fragmencie Sokrates słowem nie wspomniał o filozofach. Represje zaś wedle tego historyka dotknęły wszystkich, których imiona zaczynały się na litery wskazane przez przepowiednię. Jak więc podał Sokrates, chcąc ratować swoje życie, wielu zmieniało imiona nadane im z chwilą urodzenia ${ }^{50}$. Wydaje się zatem, że Sozomen wprowadził wątek filozofów we wspomniane opowiadanie świadomie, chcąc wykazać, że piewcy dawnej pogańskiej mądrości wyginęli.

Sokrates z Konstantynopola zwrócił też uwagę na cechującą filozofów helleńskich ciekawość świata. Historyk ten opisał przypadek niejakiego Meropiusza, filozofa z Tyru, który kierując się ambicją, miał postanowić „za wszelką cenę zwiedzić kraj Indów, bo nie chciał być gorszy od filozofa Metrodorosa, który dokonał tego przed nim" ${ }^{51}$. Sozomen, podejmując ów wątek, skonstatował, że najwybitniejszym filozofom greckim „niezmiernie zależało na tym, aby dokładnie poznać i opisać nieznane kraje i miasta" ${ }^{52}$. Wspomniał na wstępie o podróżach podjętych przez Platona, ,znakomitego ucznia Sokratesa", do Egiptu i na Sycylię, gdzie ów obejrzeć chciał kratery tamtejszych wulkanów. Kratery te oglądał także Empedokles, „wybitny myśliciel grecki i pisarz". Sozomen skoncentrował się na jego śmierci w kraterze podkreślając, że nie wiadomo dlaczego wybrał taki jej rodzaj: czy doprowadziła go do tego chęć rozwiązania zagadki „buchającego ognia”, czy też świadomie postanowił w ten sposób zakończyć życie. Historyk ten podejrzewał jednak, że filozof poniósł śmierć w sposób niezamierzony, a więc na skutek wypadku. Tak czy owak mędrzec ów wykazał się nie lada lekkomyślnością. Sozomen wskazał też na przykład Demokryta z wyspy Kos, który „,bardzo wiele zwiedził miast, badając klimat, krainy i ludy". Jego zdaniem, wspomniany przez Sokratesa Meropiusz, wybierając się w podróż do Indii, poszedł tylko śladem wielu podróżujących mędrców greckich ${ }^{53}$. Tak więc obydwaj historycy zwrócili uwagę na cechującą filozofów helleńskich ciekawość świata.

Charakterystyczne dla wywodów Sokratesa z Konstantynopola było przekonanie, że heterodoksi, odwołujący się do wielkich filozofów - niedostatecznie poznali ich dzieła, bądź nie zrozumieli właściwie zawartego w nich przesłania. W ujęciu tego historyka Aecjusz z Antiochii, twórca herezji anomejczy-

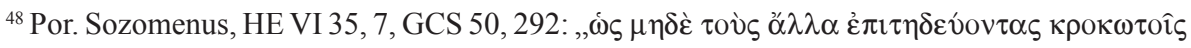

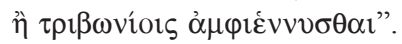

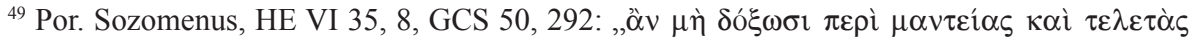

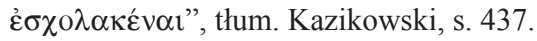

${ }^{50}$ Por. Socrates, HE IV 19.

${ }^{51}$ Por. Socrates, HE I 19, 3, GCS NF 1, 61, tłum. Kazikowski, s. 115-116.

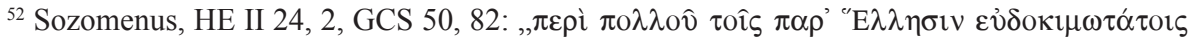

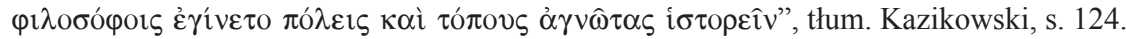

${ }^{53}$ Por. Sozomenus, HE II 24, 3-5, GCS 50, 82, thum. Kazikowski, s. 124.
} 
ków, posiadający nikłą wiedzę i słabo znający Pismo Święte, celował jedynie „W erystyce, na co stać byle durnia" ${ }^{54}$. Tenże Aecjusz, głosząc „zdumiewające nauki”, miał prowadzić dysputy teologiczne w oparciu o Kategorie Arystotelesa, których jednak, w przekonaniu Sokratesa, należycie nie zrozumiał ${ }^{55}$. Podobnie nieceniony przez historyka, kiepski teolog-heretyk, pochodzący z Kapadocji niejaki Teofronios, rozłamowiec wśród eunomian, miał z dziełami Arystotelesa być zaznajomiony jedynie $z$ grubsza ${ }^{56}$. Inaczej sytuacja przedstawiała się, zdaniem Sokratesa, w przypadku Jerzego, jednego z wybitnych mówców ariańskich, który nieustannie wertował dzieła Arytotelesa i Platona, osiagając sukcesy „,na polu nauki helleńskiej”. Historyk ten dziwił się, dlaczego Jerzy nie porzucił nauki ariańskiej, skoro zgłębiał myśl Platona. Doszedł jednak do wniosku, że Jerzy wraz z Tymoteuszem, rozmiłowanym w dziełach Orygenesa, „zmienili na lepsze religię ariańską”, rugując z niej wiele „bluźnierczych tez Ariusza” ${ }^{57}$. Można zatem skonstatować, że w przekonaniu Sokratesa ten, kto dobrze znał i rozumiał dzieła wielkich filozofów Arystotelesa i Platona, uważany był przezeń za prawdziwie mądrego, nawet jeśli był heretykiem. Natomiast ci, których uznawał za głupich, nie zgłębili należycie nauki filozofów. W każdym razie z przekazu Sokratesa wynika, iż ci, którzy chcieli uchodzić za mądrych, powoływali się na poglądy wielkich filozofów.

W przekazie Sozomena, pozbawionym estymy dla filozofii helleńskiej, łączenie poszczególnych heretyków z dziełami wielkich filozofów nie ma już takiej wymowy. Historyk ów widział w Aecjuszu człowieka podziwianego przez innowierców, wyćwiczonego w dialektyce i biegłego we wnioskowaniu sylogistycznym, oddanego bez reszty erystyce i rozmiłowanego w walkach na słowa. Dodał co prawda, że wspomniany duchowny „przebrnął przez naukową spuściznę Arystotelesa, a nawet uczęszczał w Aleksandrii do szkół nauczających w tym zakresie", ale miał to zrobić z próżności, chcąc wzbudzić jeszcze większe zachwyty w środowisku cezara Gallusa ${ }^{58}$. Teofronios, obrońca herezji Eunomiusza i jego uczeń zarazem, w relacji Sozomena nieobliczalny w swych poglądach, miał w dodatku z naukami Arystotelesa zapoznać się pobieżnie $\left(\mu \varepsilon \tau \operatorname{cí}^{\omega}\right)^{59}$. O Jerzym, wybitnym mówcy ariańskim, zgłębiającym dzieła Arystotelesa i Platona, Sozomen nie wspomniał już w ogóle.

Ocena uprawiających filozofię w Historii kościelnej Sokratesa nie była jednak tak jednoznacznie pozytywna. W jego przekonaniu:

„na krótko przed objęciem rządów przez Konstantyna obok chrystianizmu

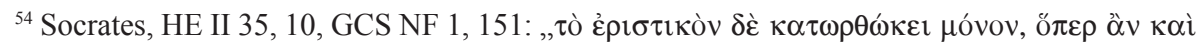

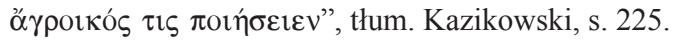

${ }^{55}$ Por. Socrates, HE II 35, 6.

${ }^{56}$ Por. Socrates, HE V 24, 2.

${ }^{57}$ Por. Socrates, VII 6, 3-9, GCS NF 1, 352, thum. Kazikowski, s. 502-503.

${ }^{58}$ Por. Sozomenus, HE III 15, 7-8, GCS 50, 126-127, thum. Kazikowski, s. 188.

${ }^{59}$ Por. Sozomenus, HE VII 17, 2, GCS 50, 325. 
prawdziwego zaczął wyrastać chrystianizm hellenizujący, zupełnie tak samo, jak to obok proroków pojawili się fałszywi prorocy, a obok apostołów - fałszywi apostołowie" 60 .

Historyk ten doszedł też do przekonania, że podobnie było z filozofami, obok tych prawdziwych pojawili się fałszywi ${ }^{61}$. Najbardziej sztandarowym przykładem dla Sokratesa był tu przypadek cesarza Juliana, który sam uważał się za filozofa ${ }^{62}$, tym bardziej że studiował filozofię w Atenach ${ }^{63}$.

Opisując okoliczności ogłoszenia Juliana cesarzem, Sokrates postawił pytanie, czy w późniejszych czynach tegoż władcy można rozpoznać działania filozofa i choć zostawił odpowiedź czytelnikom, podał jednak szereg faktów, które dezawuowały postępowanie Juliana. Obciążał go przede wszystkim winą rozpętania wojny domowej, która mogła zakończyć się morzem przelanej krwi ${ }^{64}$. Sokrates podkreślał, że w tajniki filozofii wprowadził Juliana Maksym z Efezu, uznany z czasem za szarlatana i czarnoksiężnika $(\mu \alpha \gamma \gamma \alpha v \varepsilon i ́ \alpha)^{65}$. Fałszywymi filozofami okazało się wielu mędrców z otoczenia cesarza. Wedle historyka ludzie „w płaszczach filozofów, bardzo często okazywali się filozofami raczej z wyglądu, a nie z wykształcenia"66. Sokrates wręcz nazywa ich „zgrają oszustów” (őv $\delta \rho \varepsilon \varsigma ~ \alpha ̉ \pi \alpha \tau \varepsilon \hat{\omega} v \varepsilon \varsigma)^{67}$, którzy, chcąc przypodobać się cesarzowi, przyjmowali jego poglądy na temat religii. Historyk ganił Juliana za jego krytykę panujących przed nim cesarzy w napisanym przezeń dziełku Cezarowie, w którym ten nie oszczędził nawet cesarza-filozofa Marka Aureliusza $^{68}$. Sokrates skonstatował:

„Jeśli chodzi o usunięcie z dworu kucharzy i fryzjerów, było to dzieło filozofa, ale nie cesarza. Wyszydzanie natomiast i drwiny nie są rzeczą filozofa, ale nie są także dziełem godnym cesarza. Albowiem zarówno jeden jak i drugi wyżsi są ponad wszelkie zniewagi i złośliwości. Przyznajemy cesarzowi prawo do filozofii na tyle, na ile się to nie mija ze zdrowym rozsądkiem; ale gdyby filozof miał naśladować we wszystkim cesarza, nigdy nie dopnie swego celu"69.

${ }^{60}$ Socrates, HE I 22, 1, GCS NF 1, 66: „П

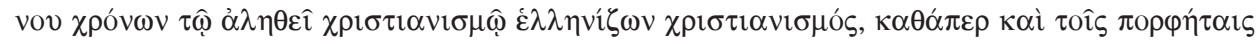

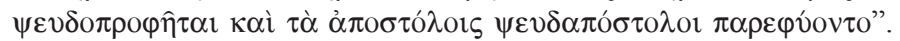

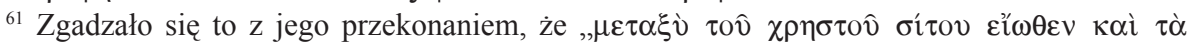

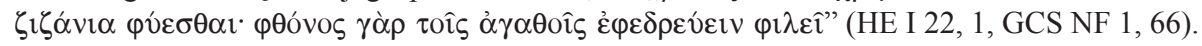

${ }^{62}$ Por. Socrates, HE III 19.

${ }^{63}$ Por. Socrates, HE III 1.

${ }^{64}$ Por. tamże.

${ }^{65}$ Por. Socrates, HE III 1, 16, GCS NF 1, 188.

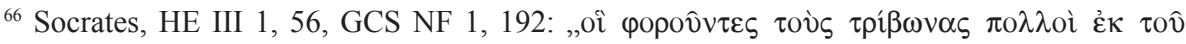

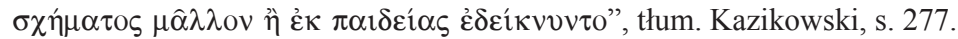

${ }^{67}$ Por. tamże.

${ }^{68}$ Por. Socrates, HE III 23, 14, GCS NF 1, 220, thum. Kazikowski, s. 316.

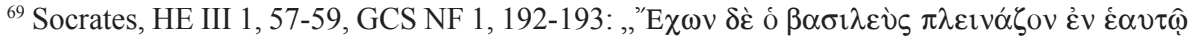

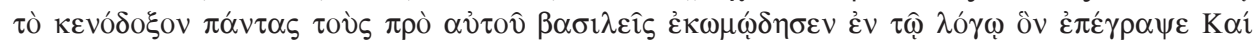


Wedle Sokratesa zatem poddawanie się złym emocjom nie było godne ani cesarza, ani filozofa.

W przekonaniu historyka sam Julian dowiódł, że nie był filozofem, kiedy przestał panować nad sobą, kipiąc gniewem przeciw chrześcijanom i tylko wyprawa perska cesarza uratowała ich wówczas przed daleko idącymi represjami $^{70}$. Prawdziwi filozofowie prowadzili życie wolne od niepokoju, a więc od wszelkiej namiętności, jak czynił to, w przekonaniu historyka, chociażby Ewagriusz Pontyjski ${ }^{71}$. Historyk zwracał ponadto uwagę na naiwność cechującą Juliana. Władca ów, marząc o sławie na miarę Aleksandra Macedońskiego, miał bowiem wierzyć w przepowiednie podsuwane mu przez fałszywego filozofa Maksyma. Dał sobie wmówić, że ma w sobie duszę Aleksandra Wielkiego, a raczej że on sam jest Aleksandrem — w drugim ciele" 72 , co doprowadziło go ostatecznie do klęski.

Sokrates uważał, że fałszywa filozofia może być groźna dla wiary chrześcijanina. Cytował list św. Pawła do Kolosan: „Baczcie, aby kto was nie zagarnął w niewolę przez tę filozofię będącą czczym oszustwem” (Kol 2, 8). Bywało, że uważani przez Sokratesa za heretyków opierali się w swym nauczaniu na filozofii. Manicheusz, twórca herezji manichejczyków ${ }^{73}$, tak jak jego poprzednicy: Scytianus Saracen i Budas zwany Terebintosem, tworząc swą doktrynę, wykorzystali filozofię Empedoklesa i Pitagorasa ${ }^{74}$. Koncepcje filozoficzne były też groźne dla samych pogan, wszak Julian, opierając się na teorii Pitagorasa i Platona o kolejnych wcieleniach, uwierzyć miał, iż jest wcieleniem Aleksandra Wielkiego ${ }^{75}$.

W swojej relacji Sokrates kojarzył z najbardziej radykalnymi poganami

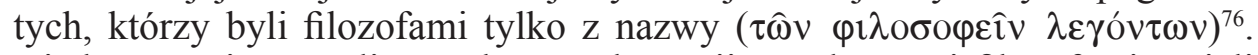
Kiedy poganie zaczęli napadać na chrześcijan, tak zwani filozofowie mieli w Atenach i w Aleksandrii oraz wielu innych miastach w tajemnych obrzędach składać ,na ofiarę niewinną młodzież, chłopców i dziewczęta, żeby wróżyć z ich wnętrzności i spożywać ich ciało". W Aleksandrii mieli intrygować

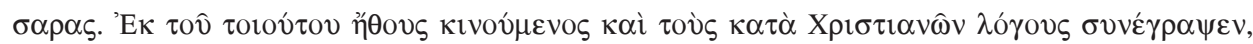

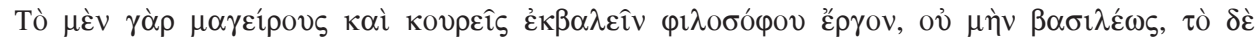

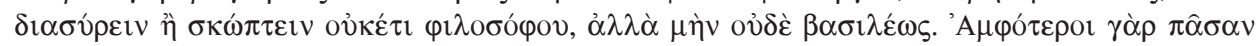

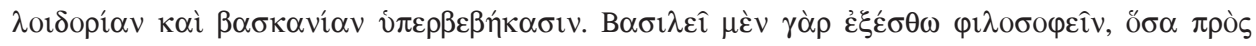

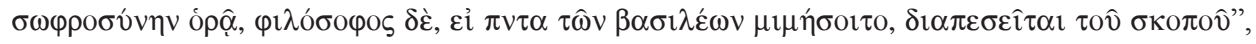
thum. Kazikowski, s. 277.

${ }^{70}$ Por. Socrates, HE III 19.

${ }^{71}$ Por. Socrates, HE VI 3.

${ }^{72}$ Socrates, HE III 21, 7, 3, GCS NF 1, 217, thum. Kazikowski, s. 311.

${ }^{73}$ Manicheizm nie był herezją, ale religią synkretyczną z elementami zoroastryzmu, buddyzmu i chrześcijaństwa.

${ }^{74}$ Sokrates popełnia błąd doszukując się wpływu Empedoklesa na naukę Manesa. Dualizm manichejski związany był z mazdaizmem i doktrynami gnostyckimi.

${ }^{75}$ Por. Socrates, HE III 21, 7.

${ }^{76}$ Socrates, HE III 13, 11, GCS NF 1, 208. 
przeciwko biskupowi Atanazemu, oskarżając go przed cesarzem o rujnowanie nie tylko miasta, ale całego Egiptu ${ }^{77}$. Kiedy zburzono pogańskie świątynie w Aleksandrii, tamtejsi poganie, a zwłaszcza ci, którzy zajmowali się filozofią, dopuścić się mieli mordów na chrześcijanach ${ }^{78}$.

Sokrates zarzucał też owym pseudofilozofom koniunkturalność. Po krótkich rządach Juliana, kiedy nastapił ponowny odwrót od pogaństwa, upodabniający się do filozofów ,zaczęli odkładać do lamusa swoje płaszcze i przebierać się w zwykłe szaty. Zaprzestali również plamić się krwią ofiar publicznych, których za rządów Juliana nadużyli do przesytu"79. To o nich powiedzieć miał cesarz Jowian, nazywając ich pochlebcami, co odnotował skrzętnie Sokrates, że „czczą oni purpurę cesarską, a nie Boga, i niczym się nie różnią od Euryposu, przerzucającego swoje nurty raz w tę, raz w przeciwną stronę" $"$.

Ludzie, chcący uchodzić za filozofów, a więc mędrców, często utożsamianych przez Sokratesa z poganami, nader chętnie przywdziewali krótki płaszcz filozofów nazywany $\tau$ $́^{\prime} \beta o v$. Jednak, jak zaznaczył Sokrates, nie był to strój odpowiadający godności kapłaństwa, o czym przekonał się Eustacjusz, biskup Sebasty w Armenii, który za przywdziewanie płaszcza filozofa został złożony z urzędu przez własnego ojca Eulaliusza, biskupa Cezarei Kapadockiej ${ }^{81}$. Znamienne, że opisujący przypadek Eustacjusza Sozomen nie wspomniał o noszeniu przez biskupa płaszcza filozofa. Nadmienił natomiast, że to niektórych z uczniów Eustacjusza oskarżano o to, iż ,unikali noszenia zwykłych tunik i płaszczy, a używali odzieży cudzoziemskiej i ekstrawaganckiej”"82. Tym niemniej zaznaczył, że po wyroku synodu w Gangra, potępiającym Eustacjusza i jego zwolenników za podobne praktyki, on sam miał zmienić natychmiast strój i odtąd ,zaczął występować publicznie ubrany podobnie jak reszta kapłanów" "83. W innym miejscu historyk podał jedynie informację o osądzeniu Eustacjusza przez jego ojca, nie podając jednak przyczyny, dla której ten wydał nań wyrok ${ }^{84}$. Wydaje się, że Sozomen świadomie łagodził krytykę Eustacjusza z racji swej fascynacji ruchem monastycznym. Wszak biskup Sebasty, co podkreślał historyk, ,jako pierwszy zaczął uprawiać życie mnicha” pośród

${ }^{77}$ Socrates, HE III 13, 11-13, GCS NF 1, 208, thum. Kazikowski, s. 299.

${ }^{78}$ Por. Socrates, HE V 16.

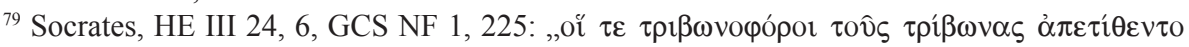

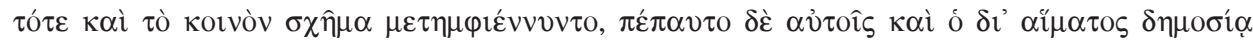

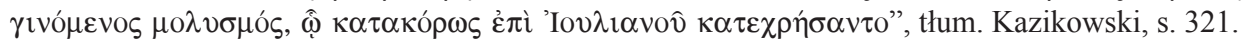

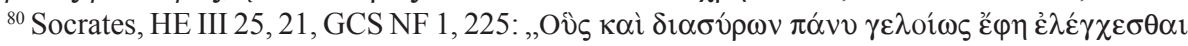

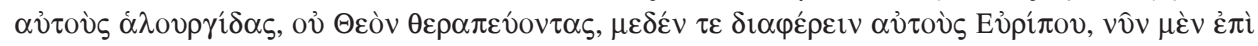

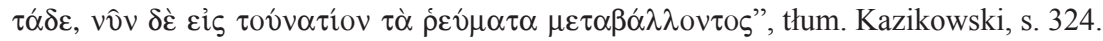

${ }^{81}$ Por. Socrates, HE II 43, 1.

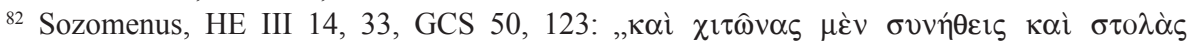

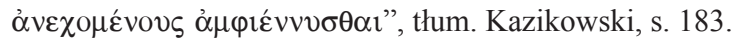

${ }^{83}$ Sozomenus, HE III 14, 36, thum. Kazikowski, s. 183.

${ }^{84}$ Por. Sozomenus, HE IV, 24, 9. 
mieszkańców Armenii, Paflagonii i Pontu, stając się na tym obszarze „twórcą ścisłej reguły życia zakonnego" 85 .

Sozomen nie doszukiwał się wśród filozofów helleńskich fałszywych filozofów. Nie miał na przykład wątpliwości co do tego, że mistrz Juliana Apostaty, Maksym z Efezu, był filozofem. Historyk łączył jednak filozofów z religią pogańska, przypisując współczesnym sobie postawę antychrześcijańską. W relacji Sozomena Maksym wprowadził Juliana Apostatę nie tylko „w świat nauk filozoficznych”, ale nauczył go też „nienawiści do religii chrześcijańskiej" 86 . Jak dowodził historyk, Apolinary z Laodycei w dziele zatytułowanym W obronie prawdy, miał wykazać, że Julian, jak i otaczający go „filozofowie zeszli na manowce i odwrócili się od należytego sposobu myślenia o Bogu"87.

Sokrates wyrażał niejednoznaczne sądy na temat sofistów. $Z$ jednej strony uważał ich za pseudouczonych, twierdząc, że sofiści urządzali kpinę z filozo$\mathrm{fii}^{88}$. Popisy sofistyczne kojarzył z wymyślnymi żartami ${ }^{89}$, jak było to w przypadku wspomnianego już Aecjusza z Antiochii, który, zdaniem historyka, nie tylko sam nie znał się na Piśmie Świętym, ale ignorował również cenionych Jego interpretatorów, takich jak Klemens Aleksandryjski, Juliusz Afrykańczyk, czy Orygenes, będących w dodatku w ocenie Sokratesa prawdziwymi filozofami ${ }^{90}$. W Historii kościelnej Sokratesa także antiocheńscy zwolennicy Aecjusza odwoływali się do sofistycznych sztuczek, usiłując „wywikłać się ze sprzeczności”, w które popadli ${ }^{91}$. Na sofistykę wysilali się też zwolennicy herezjarchy Akacjusza z Cezarei Palestyńskiej ${ }^{92}$. Z drugiej jednak strony Sokrates z Konstantynopola pisał o sławnych ateńskich sofistach Himeriuszu i Proajreziosie, którzy byli nauczycielami Bazylego z Cezarei i Grzegorza z Nazjanzu ${ }^{93}$. Bardzo pozytywnie wypowiadał się też na temat Troilosa Sofisty, który odznaczać się miał wielką mądrością, i u którego prefekt Antemiusz, kierujący wschodnią częścią Imperium Rzymskiego po śmierci cesarza Arkadiusza, zasięgał rady niemal we wszystkich sprawach polityki państwowej9 ${ }^{94}$.

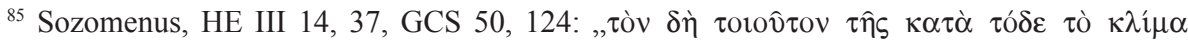

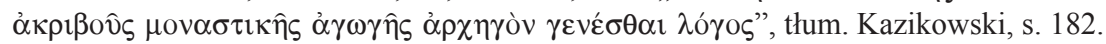

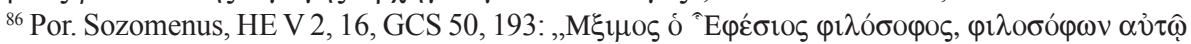

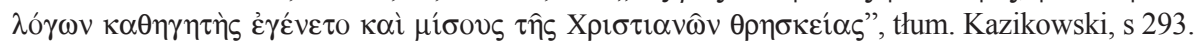

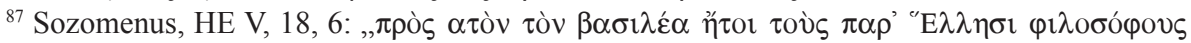

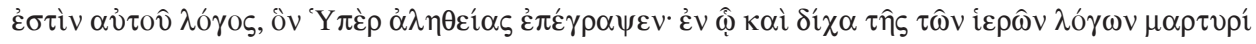

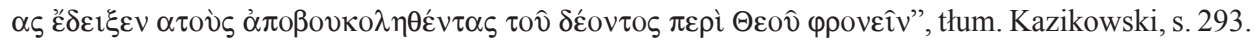

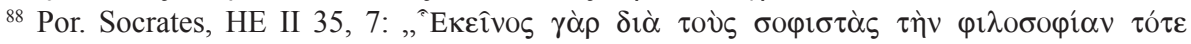
$\chi \lambda \varepsilon v \alpha ́ \zeta o v \tau \alpha{ }^{\prime \prime}$.

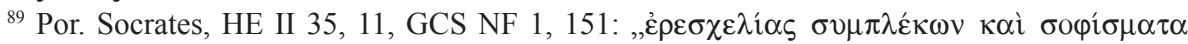
$\mu \varepsilon \lambda \varepsilon \tau \hat{\omega} v^{\prime \prime}$.

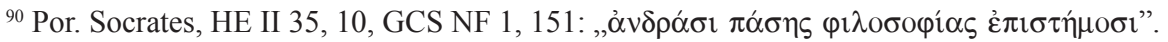

${ }^{91}$ Por. Socrates, HE II 45, 11, GCS NF 1, 184.

${ }^{92}$ Por. Socrates, HE II 45.

${ }^{93}$ Por. Socrates, HE IV, 26, 6; zob. Van Nuffelen, Un héritage, s. 14-36.

${ }^{94}$ Por. Socrates, HE VII $1,3$. 
Wydaje się, że Sozomen generalnie miał także negatywny stosunek do sofistów. W jego dziele Asteriusz, sofista z Kapadocji, popierając i propagując poglądy Ariusza, sprowokował Marcellego z Ancyry do nazbyt ostrej reakcji, na skutek czego ten popadł w błędną naukę Pawła z Samosaty ${ }^{95}$. Negatywnie oceniany przez Sozomena Aecjusz Syryjczyk wyróżniał się przesadnym zamiłowaniem do erystyki typowej dla sofistów ${ }^{96}$. W relacji Sozomena Bazyli z Ancyry miał stosować sofistyczne chwyty, chcąc „wykręcić się od zarzutu krzywoprzysięstwa" ${ }^{97}$. Historyk, idąc za przekazem Sokratesa, pisał jednak także o nauczycielach Bazylego z Cezarei i Grzegorza z Nazjanzu - Himeriuszu i Proajreziosie, których nazywa najsławniejszymi wówczas sofistami w Atenach ${ }^{98}$. Ich nauczycielem miał być także Libaniusz ${ }^{99}$, którego Sozomen nazywa znanym sofistą ${ }^{100}$. Sławnym w swoim czasie sofistą historyk określał także Epifaniusza, który dawał wykłady w Laodycei ${ }^{101}$.

Obok fałszywej filozofii Sokrates rozróżniał filozofię uprawianą czynem i filozofię uprawianą słowem. Na przykładzie Ewagriusza Pontyjskiego wskazuje, że pierwsza z wymienionych była wyższym stopniem wtajemniczenia, gdyż wspomniany mnich najpierw zdobył umiejętność filozofowania słowem, po czym dopiero dzięki swoim mistrzom -Makaremu z Egiptu i Makaremu z Aleksandrii nauczył się stosować filozofię $\mathrm{w}$ praktyce ${ }^{102}$. W efekcie czego, o czym informował Sokrates: „sprawił swą ręką tyle samo cudownych znaków, co i jego nauczyciele" ${ }^{103}$. W relacji historyka obydwaj mistrzowie Ewagriusza, wyróżniając się ogromem cnót, prowadzili życie ascetyczne i dokonywali wielu cudów. Szczególnie wyróżnił się przy tym Makary egipski, który zdaniem Sokratesa:

„dokonał tylu cudownych uzdrowień, z tylu opętanych wypędził złego ducha, że to, czego on dokonał za łaską Bożą, wymagałoby oddzielnej księgi”'104.

Widać zatem, że dla historyka prawdziwymi mędrcami byli mnisi poprzez swoje ascetyczne życie odkrywający Boga, którego jednym z przydomków była Mądrość-Sophia ${ }^{105}$. Uprawianie filozofii czynem prowadziło zatem do

\footnotetext{
${ }^{95}$ Por. Sozomenus, HE II 33, 4.

${ }^{96}$ Por. Sozomenus, HE IV, 12, 2.

${ }^{97}$ Por. Sozomenus, HE IV, 24, 6, GCS 50, 179, thum. Kazikowski, s. 271.

${ }^{98}$ Por. Sozomenus, HE VI 17, 1.

${ }^{99}$ Por. tamże.

${ }^{100}$ Por. Sozomenus, HE VIII 2, 2.

${ }^{101}$ Por. Sozomenus, HE VI 25, 9.

${ }_{102}$ Por. Socrates, HE IV 23, 32-34.

${ }^{103}$ Por. Socrates, HE IV 23, 35, GCS NF 1, 253, thum. Kazikowski, s. 362.

${ }^{104}$ Socrates, HE IV 23, 31, GCS NF 1, 252, thum. Kazikowski, s. 361.

${ }^{105}$ Por. Socrates, HE I 6; II 10; II 18; II 19; II 30; II 40.
} 
bliskich relacji z Bogiem. Ci, w których „mieszkała świętość”, jak ujął to Sokrates $^{106}$, ciesząc się wielką łaską u Boga, mieli moc dokonywania cudów ${ }^{107}$.

Wydaje się, że filozofię uprawianą czynem Sokrates uważał za prawdziwą filozofię. W jego relacji bowiem Grzegorz z Neocezarei w Poncie, wyszkolony przez Orygenesa w prawdziwej filozofii ${ }^{108}$, miał uczynić wiele znaków, lecząc chorych i wyrzucając złe duchy. Nadano mu przydomek Cudotwórcy, i jak zapewniał Sokrates, był znany nie tylko w Atenach (stolicy filozofii), w Berytos - diecezji Pontu, ale na całym świecie. Nauczanie Orygenesa, o czym informował historyk, dotyczyło w dużej mierze interpretacji Pisma Świętego ${ }^{109}$. Bazyli z Cezarei i Grzegorz z Nazjanzu zapoznali się z nią, studiując dzieła Orygenesa ${ }^{110}$, gdyż jego sława, jak dowodził Sokrates, rozchodziła się wówczas szeroko po całej ziemi. Prawdziwa filozofia opierała się zatem na bardzo dobrej znajomości Pisma Świętego i była, w ujęciu historyka, najwyższym stopniem wykształcenia ${ }^{111}$.

Sokrates z Konstantynopola, pisząc o zaletach cesarza Teodozjusza II wskazał, iż ten na zawsze porzucił sylogizmy Arystotelesa, a filozofię uprawiał czynem, ,panując nad gniewem, rozdrażnieniem czy rozkoszą zmysłową" 112 . Historyk zestawił Teodozjusza z cesarzem Julianem, który, co podkreślił, uchodził za filozofa, a nie panował nad uczuciem gniewu ${ }^{113}$. Przeciwstawił zatem sobie nawzajem dwóch władców, których w swoim dziele oceniał odmiennie, tworząc dwa różne portrety - pozytywny Teodozjusza II i negatywny - Juliana. Kluczem do oceny obydwu cesarzy stała się dla Sokratesa ich postawa życiowa, którą wiązał z ich podejściem do filozofii. Pierwszy z nich, rezygnując z czczych dociekań intelektualnych, potrafił okiełznać swe namiętności, w czym dostrzegał historyk praktyczną mądrość, podczas gdy drugi nie radził sobie z uczuciem gniewu, choć uważał się za filozofa. W przekonaniu Sokratesa zatem z wymienionej dwójki prawdziwym filozofem był jedynie wolny od namiętności Teodozjusz. Kwestię tę rozwinął historyk, przytaczając wywód Bazylego z Kapadocji, rozróżniającego wiedzę pochodzącą od ludzi i wiedzę wewnętrzną, której źródłem jest łaska Boża, i do której przyjęcia zdolni byli jedynie ludzie wolni od namiętności ${ }^{114}$.

\footnotetext{
${ }^{106}$ Socrates, HE IV 23, 77, GCS NF 1, 256, thum. Kazikowski, s. 365.

${ }^{107}$ Sokrates (HE I 11) dowodzi tego, omawiając dokonania biskupa Pafnucego. Podobnie, w jego relacji (HE I 19, 14), Frumencjusz: ,zaszczycony łaską Bożą dokonywał wielu cudów i znaków, a niejednokrotnie lecząc dusze ludzkie leczył także i ciała" (Kazikowski, s. 117).

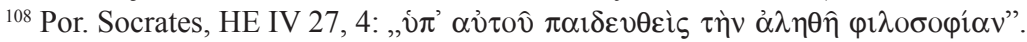

${ }^{109}$ Por. Socrates, HE IV 27.

${ }^{110}$ Por. Socrates, HE IV 26, 8-10.

${ }^{111}$ Bazyli i Grzegorz, co podkreślał Sokrates, byli biegli nie tylko w nauce helleńskiej, ale też w nauce opartej na Piśmie Świętym, a jego interpretacji uczyli się z dzieł Orygenesa.

112 Por. Socrates, HE VII 22 8, GCS NF 1, 369, Kazikowski, s. 525.

${ }^{113}$ Por. Socrates, HE VII 22, 6-7.

114 Por. Socrates, HE IV 23, 66-67. Widać tu wpływ stoicyzmu i cynizmu greckiego, tym
} 
W przekonaniu Sokratesa najwyższym stopniem mądrości odznaczali się ci, którzy wybrali drogę chrześcijańskiej ascezy, a więc życie mnicha, nowego rodzaju mędrca. Tak uczynili Bazyli z Cezarei i Grzegorz z Nazjanzu, porzuciwszy sofistykę i wybierając życie pustelnicze ${ }^{115}$. Podobnie postąpili Ewagriusz Pontyjski i Jan Chryzostom, który zmienił „strój i sposób poruszania się, i skupił swą uwagę na lekturze Pisma Świętego, a ponadto często i gorliwie spieszył do kościoła”. Jan przekonał ponadto Teodora i Maksyma, którzy tak jak on byli uczniami retora Libaniusza ,do porzucenia życia zmierzającego do zdobycia zysku, a obrania życia skromnego i prostego" "116. Sama dialektyczna mądrość okazywała się także bezużyteczna, jak było w przypadku Aleksandra, biskupa Konstantynopola, który czując się bezradny wobec triumfu herezjarchy Ariusza, miał ją odrzucić i schronić się pod opiekę Boża, a nieustanną modlitwą i postem wyprosić karę dla Ariusza ${ }^{117}$.

Wedle Sokratesa z Konstantynopola to dopiero mędrcy chrześcijańscy byli w stanie poznać Boga w sposób o wiele doskonalszy od filozofów helleńskich, dzięki Jego łasce i to nawet wtedy, kiedy nie mieli stosownego wykształcenia. Jak wskazywał Sokrates, uczestnicy soboru w Nicei, nawet gdyby byli ludźmi prostymi, to dzięki światłości zesłanej na nich przez Boga i łasce Ducha Świętego „nie mogli rozminąć się z prawdą”"118. W relacji historyka, kiedy przed wspomnianym soborem dialektycy urządzili zawody w walce na słowa, ,pewien człowiek świecki z grona wyznawców, obdarzony zdrowym rozsądkiem, stawia czoło dialektykom", wskazując, że Chrystus i apostołowie ,przekazali nam nie sztukę wymowy ani puste chwyty, lecz czystą naukę, której strzeże wiara i dobre uczynki”. Dialektycy „usłyszawszy proste słowo prawdy", mieli zrezygnować z dalszych popisów ${ }^{119}$. Sokrates wyraźnie poruszony był też odpowiedzią udzieloną przez słynnego mnicha Antoniego, twórcę anachoretyzmu, będącego analfabetą, na pytanie jednego ze współczesnych mędrców o to, jak ten może wytrzymać bez książek. Filozof usłyszał, iż książką dla owego mnicha była natura stworzenia, w której zawsze, kiedy zechce może, odczytywać słowa samego Boga ${ }^{120}$. Chrześcijańscy mędrcy zatem odkrywali prawdę dzięki łasce Boga i to nawet wtedy, kiedy po ludzku sądząc, byli do tego zupełnie nieprzygotowani, będąc ludźmi prostymi, kompletnie niewyedukowanymi.

bardziej, że Sokrates wspomina w swoim dziele (HE III 23) o przedstawicielu tego ostatniego nurtu - Diogenesie.

${ }^{115}$ Por. Socrates, HE IV 26, 7.

${ }^{116}$ Por. Socrates, HE VI 3, 3-4, GCS NF 1, 314, tłum. Kazikowski, s. 450; zob. też Sozomenus,

HE VIII 2.

${ }^{117}$ Por. Socrates, HE I 37.

${ }^{118}$ Por. Socrates, HE I 9, 28, GCS NF 1, 33, thum. Kazikowski, s. 91.

${ }_{119}$ Por. Socrates, HE I 8, 15-16, GCS NF 1, 19, thum. Kazikowski, s. 78.

${ }^{120}$ Por. Socrates, HE IV 23. 
Wydaje się, że Sozomen myślał na ten temat bardzo podobnie do Sokratesa, jak świadczy opisana przez niego historia Efrema Syryjczyka. W przekonaniu historyka, mimo że ów nie uczył się, doszedł do tak wielkiej wiedzy, ,że w filozofii mógł z powodzeniem rozpatrywać najsubtelniejsze zagadnienia, a giętkością i błyskotliwością mowy, głębią i mądrością myśli przewyższał najsławniejszych pisarzy helleńskich"121. W innym zaś miejscu Sozomen pisał, iż wedle ówczesnych elit intelektualnych „w zakresie kultury słowa Efrem przewyższał wszystkich współczesnych sobie pisarzy i mówców"122.

Swoje poglądy na temat filozofii chrześcijańskiej wyłożył Sozomen w I księdze swej Historii kościelnej w rozdziale 12. Historyk uważał ideały

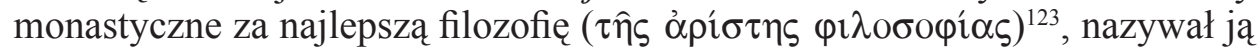

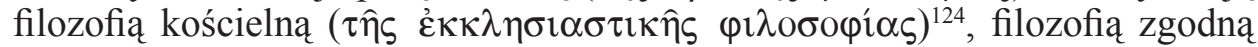
$\mathrm{z}$ prawami Kościoła ${ }^{125}$. Filozofia ta stała się dla wielu sposobem życia ( $\tau 0 \hat{\text { Bí }}$

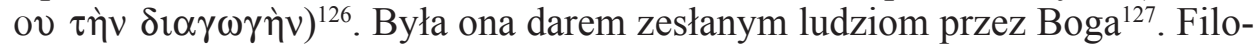
zofię tę, zapoczątkowaną przez proroka Eliasza, a potem rozwijaną przez Jana Chrzciciela, uprawiali generalnie wszyscy chrześcijańscy asceci, począwszy od mnichów w Egipcie. Wspomnianego terminu Sozomen użył w odniesieniu do Antoniego, który filozofię doprowadzić miał do najwyższej doskonałości ${ }^{128}$, a także Pachomiusza, który miał w niej osiągnać doskonałe rezultaty ${ }^{129}$. Egipcjanie przekazali ją potem mieszkańcom Palestyny ${ }^{130}$, gdzie uprawiali ją tamtejsi mnisi, jak choćby Hilarion, który zdecydował się na ten krok po rozmowie ze wspomnianym słynnym mnichem Antonim ${ }^{131}$, czy Aleksy z Bethagathonu i Alafion z Asalei w Palestynie, którzy mieli wkroczyć na drogę filozofii z pobożnością i odwaga ${ }^{132}$. Filozofię uprawiali tam też cieszący się wielką sławą mnisi Salamanes, Fyskon, Malchion i Kryspion ${ }^{133}$. Według Sozomena Bazyli

${ }^{121}$ Por. Sozomenus, HE III 16, 1, GCS 50, 127, thum. Kazikowski, s. 188.

${ }^{122}$ Por. Sozomenus, HE III 16, 3, GCS 50, 128, thum. Kazikowski, s. 189.

${ }^{123}$ Por. Sozomenus, HE I 12, 9, GCS 50, 26.

${ }^{124}$ Por. Sozomenus, HE IV 16, 11, GCS 50, 160.

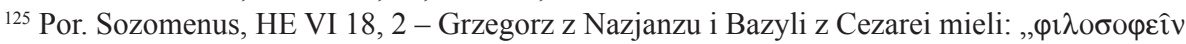

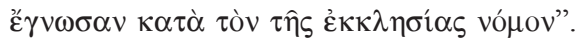

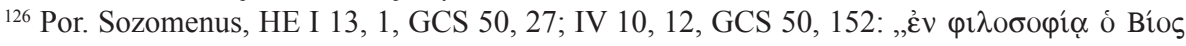

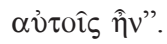

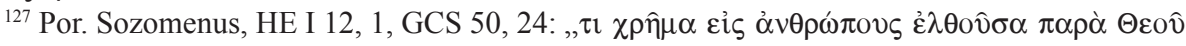

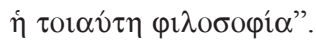

${ }^{128}$ Por. Sozomenus, HE I 13, 1, GCS 50, 27.

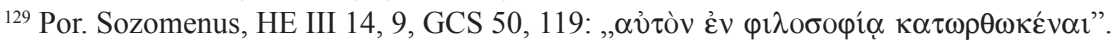

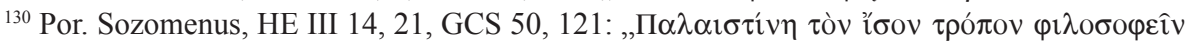

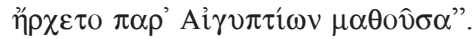

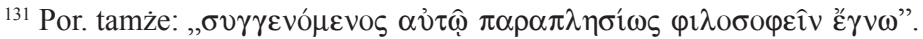

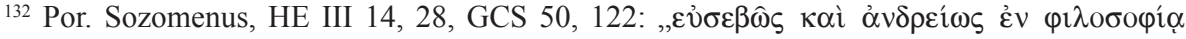
$\varepsilon \dot{\varepsilon} \pi \mathrm{\partial} \iota \tau \varepsilon \dot{\sigma} \sigma \alpha \nu \tau 0 "$

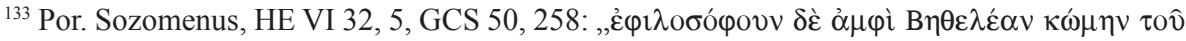

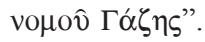


z Cezarei słynął nie tylko z daru wymowy, ale umiłowania Boga i życia filozofią $^{134}$. Filozofia ta, oparta na sile umysłu czerpiącego swą moc od Boga, nie rozwijała umiejętności prowadzenia dysput, uznając je za całkowicie nieprzydatne. Jej celem było życie według zasad sprawiedliwości, wolne od przewrotności, dążące do moralnego dobra. Uczyła ona wcielać cnotę w życie, stawiać czoło słabości ducha i ciała, wyzbywać się wszelkich namiętności, umiaru we wszystkim, rezygnowania z rzeczy materialnych. Nakazywała troszczyć się o potrzebujących. Jednocześnie była całkowicie ukierunkowana na Boga. Miała prowadzić do życia jak najbliżej Niego. Do oddawania Mu czci dniem i nocą. Jej zadaniem było przebłaganie Stwórcy wszechrzeczy nieustannymi modłami. Sposobiła też do godnego wyznania wiary czystością ducha i spełnianiem dobrych uczynków. Jej zasadniczym celem był udział w radości nieba i temu podporządkowywała życie doczesne ${ }^{135}$.

Podsumowując trzeba stwierdzić, że Sokrates rozróżniał dwa rodzaje filozofii: uprawianą słowem - charakterystyczną dla filozofów helleńskich i uprawianą czynem - właściwą dla ascetów chrześcijańskich. Drugą z nich uznawał za prawdziwą filozofię zdolną odkryć prawdę o Bogu, która była najważniejszym zadaniem stojącym przed filozofami. Uprawianie jej mogło być udziałem także człowieka prostego, bez żadnego wykształcenia, a to za pośrednictwem łaski Bożej i wewnętrznego światła pochodzącego od Boga. Prawdziwa filozofia opierała się też na bardzo dobrej znajomości Pisma Świętego i stanowiła najwyższy stopień wykształcenia. Potwierdzeniem uprawiania prawdziwej filozofii były cudowne znaki czynione przez chrześcijańskich mędrców. Sokrates uważał jednak wykształcenie helleńskie, którego zwieńczeniem były studia filozoficzne, za niezwykle przydatne szczególnie do zwalczania pogaństwa, ale także do doskonalenia wymowy i rozwijania umiejętności logicznego myślenia. Podkreślał, że wielu pogańskich mędrców bliskich było odkrycia Boga. Historyk wskazywał też na szacunek, jakim filozofowie cieszyli się w społeczeństwie. Świadom był jednak także istnienia fałszywych filozofów z eksponowanym przezeń cesarzem Julianem Apostatą, który w przeciwieństwie do prawdziwych filozofów poddawał się namiętnościom. Podszywający się pod filozofów oddani byli na ogół kultom pogańskim, posługiwali się oszustwem, cechowała ich koniunkturalność i łatwo zmieniali poglądy. Chętnie nosili wyróżniające ich płaszcze i rywalizowali między sobą. W rzeczywistości nie byli jednak filozofami, tak jak nim nie był cesarz Julian Apostata, mimo że sam za takiego się uważał.

Nieco inaczej do filozofii podszedł w swym dziele Hermiasz Sozomen. On również rozróżniał dwa rodzaje filozofii - filozofię helleńską i filozofię kościelną. Pierwszą z nich wiązał ściśle z pogaństwem i przypisywał jej adep-

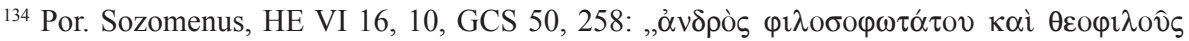

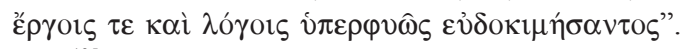

${ }^{135}$ Por. Sozomen, HE I 12. 
tom zamiłowanie do czczych dysput. Sozomen przeciwnie do Sokratesa nie przypisywał filozofii klasycznej żadnej wartości. Nie dzielił też filozofów helleńskich na prawdziwych i fałszywych. Ogólnie przypisywał im jako zasadniczą cechę lekkomyślność, która stała się powodem ich zagłady. Wskazywał na narodziny nowej filozofii zesłanej przez Boga, która była sposobem życia ukierunkowanego całkowicie na Stwórcę. Owa filozofia opierająca się na ascetycznych praktykach nie wymagała wykształcenia, gdyż oparta była na sile umysłu czerpiącego swą moc od Boga. Dzięki wielu praktykującym ją mnichom położyła wielkie zasługi dla szerzenia się chrześcijaństwa. Wydaje się, że dzieło Sozomena zawiera kluczowe przesłanie. Tak jak przeminęła era pogan, przeminęła ich mądrość i ci, którzy ją umiłowali; stąd znajdujący się w jego Historii kościelnej wywód na temat zagłady filozofów helleńskich. Zastapili ich nowi filozofowie-asceci chrześcijańscy, skupieni przede wszystkim w rozwijającym się żywiołowo ruchu monastycznym. Przeciwnie do filozofów helleńskich, ściśle związanych z pogaństwem, nowi filozofowie oddani byli wierze chrześcijańskiej.

\section{EXTERMINATION OF HELLENISTIC PHILOSOPHERS \\ IN THE ROMAN EMPIRE - THE IMAGE OF THE THINKERS IN THE ECCLESIASTICAL HISTORIES OF SOCRATES AND SOZOMEN}

\section{(Summary)}

Socrates of Constantinople, the author of the Ecclesiastical History, distinguishes between two types of philosophy: one practised by the use of words and the second reflected in deeds. The reason why the latter was considered by Socrates to be the true philosophy was the fact that it was the way to find God. That, at the same time, was the most important exercise for philosophers. According to historians even an ordinary uneducated man, could also practise philosophy. However, Socrates believed that having Hellenic education with philosophical studies, was extremely useful for stopping the paganism, in particular. What is more, it enabled speech enhancement and development of the ability to think logically. He pointed out that a lot of sages were near the discovery of God. But he was aware of the existence of false philosophers with the emperor Julian the Apostate, who, unlike true philosophers, was still subject to the passions. By impersonating of the true philosophers they were cheaters and easily changed their views, in addition professed pagan cults. Sozomen also distinguished two types of philosophy: the Hellenic philosophy and the philosophy of church. Unlike Socrates, Sozomen did not attribute any value to the classical philosophy. He did not divide the philosophers into true and false. It seems that the work of Sozomen contains a crucial message. As the period of pagans quickly passed so did their wisdom and those who loved them. Thus, information about the extermination of Hellenistic philosophers was included in his Ecclesiastical History. They were replaced with Christian philosophers gathered in the monastic movement developing vigorously. 